\section{Organelle by organelle}

The Cell in Medical Science. Vol. 1: The Cell and Its Organelles. Pp. xiii +366. $£ 7.80 ; \$ 20.25$. Vol. 2. Cellular Genetics, Development and Cellular Specialization. Pp. xvii +597 . $£ 11.30 ; \$ 29.25$. Edited by F. Beck and J. B. Lloyd. (Academic: London and New York, January 1975.)

THESE are the first two volumes of a four volume series on The Cell in Medical Science, which is primarily intended to provide the basis of a cell-science course for advanced biological sciences students and for medical students specialising in cell biology during an elective period or during an intercalated year leading to an honours degree.

Volume 1 is concerned with the generalised cell unit and with the biophysical and biochemical basis of the structure and function of the chief subcellular organelles. Its eight chapters deal with the cell as a unit, membranes and transmembrane transport, the cell surface, the nucleus, cytomembranes and ribosomes, mitochondria and peroxisomes, and subcellular pathology. Though rather poorly illustrated, this volume contains a great deal of useful information and its chapters are mostly well written. That by the editors is a particularly well-balanced treatment of lysosome structure and function and lysosome pathology, pharmacology and toxicology. In my opinion, however, this volume fails to indicate (in spite of promises in the Preface) "the directions in which contemporary cell biology is moving and the methods it uses". This is because, with its traditional, anatomical, organelle-by-organelle approach, little attention is given to the current topics which excite cell biologists -for example, cell fusion and cell hybridisation, cell cooperation, nuclear

\section{Elements of pollution}

Chemistry and Pollution. Edited by F. R. Benn and C. A. McAuliffe Pp. 156. (Macmillan: London and Basingstoke, July 1975.) £8.95.

OVER the past decade there has been much talk of pollution in all its variations, unfortunately in many instances from individuals who were unaware of even the most basic knowledge of the processes involved. This book provides an introduction to the chemistry of the processes of pollution aimed at those individuals with a background of GCE " $A$ " level chemistry; first-year university chemistry in North America. To transplantation, the translation of mammalian mRNA in amphibian oocytes, and the use of cell and organ culture techniques.

The first half of Volume 2 is concerned with cell genetics and development, and begins with four excellent, informative and readable chapters on biochemical genetics, general mammalian cytogenetics, human cytogenetics, and sex chromatin. A very useful chapter on the kinetics of cell production is followed by considerations of cell differentiation, growth and morphogenesis, and ageing. The remainder of Volume 2 comprises comprehensive and, on the whole, well-illustrated chapters on the main cell types and special structures of the neuromuscular system, including the neurone, the synapse, satellite cells of neurones, the skeletal muscle cell, the muscle spindle, and the smooth muscle cell. This theme of morphological adaptation for specific functional purposes will also occupy the whole of Volume 3, in which connective tissues, various endocrine cells, and absorptive and secretory cells will be considered.

In many of the chapters in these first two volumes, medical students would have appreciated more information on cellular aspects of abnormal and disease conditions, at the expense of some of the biochemical, biophysical, physiological and anatomical detail. The balance will to some extent be restored by the publication of Volume 4, which, following chapters on metabolic control mechanisms, will deal with the relationship between the cell and its environment in certain pathological states, including immunological processes, inflammation, wound healing, and carcinogenesis.

The Cell in Medical Science is an essential addition to all medical school and science libraries, where it will be valuable for teachers and research workers, as well as for senior undergraduates.

Michael Balls

obtain adequate in-depth coverage the editors have called on eight contributors to write the six chapters.

The stated objective of the text is to provide a factual chemical background to pollution. As might be expected, with eight authors the depth of coverage in each chapter is rather uneven and this is perhaps the most irritating aspect of the book. Reference to literature and events outside the UK is rather limited and this might limit its acceptance abroad. The authors recommend the book to universities and colleges for use in environmental pollution courses at the lower undergraduate level. It is adequate for this task. There are no problems set. The book is well produced and has an adequate index.

M. A. Ward

\section{Politics at sea}

New Era of Ocean Politics. (Studies in International Affairs, No. 22.) By Ann L. Hollick and Robert E. Osgood. Pp.xi+ 131. (Johns Hopkins University Press: Baltimore and London, April 1975.) $£ 4.40$ cloth; $£ 1.40$ paper.

THESE studies are confined to US policies and interests in the oceans, the first having particular reference to the Third United Nations Conference on the Law of the Sea and the effect that the different proposals developed there will have for the US. Apart from a little more than one page entitled "International Perspective", however, no attempt has been made to look at the policies from a global standpoint. Having said this, however, it should be remarked that the studies are a very useful contribution to the literature on the Law of the Sea and every participant in the UN Conference should own a copy, or at least have access to one, so as to gain an insight into both the US position in their particular fields and the reasoning behind US statements and activities.

Ann Hollick's study is of greater interest to the marine scientist even though, as is inevitable in a field such as this, it was partially obsolete before it was published, dating from the end of the third (Caracas) session of the Conference in mid-1974; even the outcome of that session is only lightly touched upon. Much, too, has since happened at the recent, fourth session in Geneva.

Consideration of the US position on Marine Pollution and Scientific Research has been confined to some six pages which discuss, first, the reason for including marine pollution within the competence of the conference (this happened because of Canadian insistence after the Manhattan voyage through the North-West Passage in the summer of 1969) and second, how late in the proceedings (summer 1973) the US formulated a policy of Scientific Research; before that, US policy had been almost entirely dominated by petroleum-defence interests. Nonetheless, the US was one of the first countries seriously to consider marine scientific interests at all.

The second study, by Robert Osgood, is an interesting account of US security (that is, military) interests in the oceans, and the surrounding legal implications. This section is of lesser concern to the marine scientist though it does show why US policy has developed as it has, sometimes to the detriment of scientific interests.

The book is well produced and readable in spite of its specialist interest. This is partly a result of a number of fascinating insights into the workings of US government (no doubt others operate in similar fashion but one seldom gets the opportunity to read about them).

Desmond P. D. Scott 